\title{
PEMETAAN PERMASALAHAN PENDIDIKAN ISLAM DI INDONESIA DAN LANGKAH-LANGKAH MENGATASINYA
}

\section{Tiy Kusmarrabbi Karo}

Dosen Program Studi Pendidikan Bahasa Arab STAI As-Sunnah Deli Serdang Jl. Medan-Tg. Morawa, Km. 13 G. Darmo, Desa B. Sari, Kec. Tg. Morawa Kab. D. Serdang

Kusma70@yahoo.co.id

\begin{abstract}
Abstrak: Pendidikan Islam di Indonesia telah berlangsung sejak masuknya Islam ke Indonesia. Sejalan dengan perkembangan zaman, timbul permasalahanpermasalahan pendidikan yang kompleks, yang membelit percepatan perkembangan dan kemajuannya. Masalah tersebut meliputi kelembagaan, kepemimpinan, keuangan, kepegawaian, kurikulum, kesiswaan, dukungan masyarakat, tingkat kepercayaan, konflik, dan sebagainya. Hingga kinimasyarakat menangkap citra lembaga pendidikan Islam sebagai lembaga pendidikan "kelas dua". Sungguh istilah pendidikan "kelas dua" tidak hanya mencerminkan penilaian objektif-empirik, tetapi juga merupakan pelecehan. Kenyataan tersebut jelas akan melahirkan stigma negatif terhadap eksistensi lembaga pendidikan Islam. Jika stigma negatif ini masih melekat dan diyakini kebenarannya oleh masyarakat luas, maka sudah tentu juga akan berdampak negatif terhadap masa depan pendidikan Islam. Tulisan ini berusaha memetakan permasalahan-permasalahan pendidikan Islam di Indonesia dan langkah-langkah strategis untuk mengatasinya. Perlu pula dikemukakan bahwa permasalahan pendidikan yang diuraikan dalam tulisan ini terbatas pada permasalahan pendidikan formal.
\end{abstract}

Kata Kunci: Permasalahan Pendidikan Islam dan Langkah-langkah mengatasinya

\section{Pendahuluan}

Salah satu amanat Undang-Undang Dasar 1945 kemudian diatur lebih lanjut dalam Undang-Undang Nomor 20 tahun 2003 tentang Sistem Pendidikan Nasional yang memiliki visi terwujudnya sistem pendidikan sebagai pranata sosial yang kuat dan berwibawa untuk memberdayakan semua warga negara Indonesia berkembang menjadi manusia yang berkualitas sehingga mampu dan proaktif menjawab tantangan zaman yang selalu berubah.

Sejalan dengan perkembangan zaman, maka timbul permasalahanpermasalahan pendidikan yang kompleks. Berbagai persoalan pendidikan muncul dan berkembang seperti rendahnya kualitas pendidikan secara umum, masalah anggaran pendidikan, tidak meratanya kesempatan pendidikan, dan mahalnya biaya pendidikan. Dan lebih khusus lagi, problematika juga terjadi pada profesi keguruan yang merupakan ujung tombak dunia pendidikan. Beberapa 
permasalahan yang teridentifikasi antara lain rendahnya kualitas guru, tidak profesional dalam melaksanakan tugas keguruan, kurangnya penghargaan masyarakat terhadap profesi guru, dan tingkat kesejahteraan guru yang relatif masih rendah.

Dan lebih ironi lagi, Indonesia merupakan negara yang mayoritas Muslim. Akan tetapi dalam hal pendidikan, pendidikan Islam tidak menjadi mayoritas dalam kedudukan pendidikan nasional. Sudah menjadi rahasia umum bahwa pendidikan Islam dipandang selalu berada pada posisi deretan kedua atau posisi marginal dalam sistem pendidikan nasional. Padahal, pendidikan apapun itu, baik pendidikan nasional ataupun pendidikan Islam, pada hakikatnya pendidikan adalah mengembangkan harkat dan martabat manusia, memanusiakan manusia agar benar-benar mampu menjadi khalifah di atas bumi ini.

Stigma negatif terhadap lembaga pendidikan Islam rasanya tidakperlu direspon secara reaktif karena mungkin saja stigma tersebutmemang mencerminkan kebenaran substansi pendidikan Islam.Respon yang terbaik adalah melakukan pembenahan, penggodokan,dan pembenahan strategi manajerial maupun leadership-nya.Perubahan yang dimaksud adalah merevisi strategistrategikonvensional menjadi strategi-strategi transformatif, di mana strategiini akan memberdayakan potensi-potensi yang dimiliki oleh lembagapendidikan Islam menjadi kekuatan yang andal dalam mengawal,mengantarkan, dan mewujudkan keberhasilan dan kemajuan lembagapendidikan Islam, baik secara fisik maupun kualitasnya.

\section{Makna Permasalahan/Problematika Pendidikan Islam}

Permasalahan sinonim dari kata problematika atau persoalan, problematika berasal dari akar kata bahasa Inggris "problem" artinya, soal, masalah atau tekateki. Juga berarti problematik, yaitu ketidaktentuan. Adapun yang dimaksud dengan problematika pendidikan adalah, persoalan-persoalan atau permasalahan yang dihadapi oleh pendidikan, khususnya Negara Indonesia. ${ }^{1}$

Pendidikan adalah usaha sadar dan terencana untuk mewujudkan suasana belajar dan proses pembelajaran agar peserta didik secara aktif mengembangkan

${ }^{1}$ Mochtar Buchori. Spektrum Problematika Pendidikan di Indonesia (Yogyakarta: Tiara Wacana 1994), h. 46-47. 
potensi dirinya untuk memiliki kekuatan spritual keagamaan, pengendalian diri, kepribadian, kecerdasan, akhlak mulia, serta keterampilan yang diperlukan dirinya, masyarakat, bangsa dan negara. Pendidikan berintikan interaksi antara pendidik dan peserta didik dalam upaya membantu peserta didik menguasai tujuan-tujuan pendidikan. Interaksi pendidikan dapat berlangsung dalam lingkungan keluarga, sekolah, ataupun masyarakat. Dengan kata lain bahwa pendidikan dalam praktiknya dapat dikelompokkan menjadi tiga, yakni pendidikan informal (keluarga), formal (sekolah), dan nonformal (masyarakat). Sehingga sebenarnya keberhasilan pendidikan nasional sangat bergantung terhadap ketiganya.

Dari ketiga jenis pendidikan tersebut di atas, pendidikan formallah yang mendapat sorotan paling tajam. Hal ini dapat dimaklumi karena keterbatasan wawasan masyarakat tentang hakikat pendidikan, dan perangkat pendidikan formal secara umummemang relatif lebih memadai dibandingkan dengan pendidikan informal dan nonformal.

PendidikanIslam pada umumnya mengacu kepada terminologi atTarbiyah, al-Ta'dib dan al-Ta'lim, pengertian dasarnya menunjukkan makna tumbuh, berkembang, memelihara, merawat, mengatur, menjaga kelestarian dan eksistensinya. ${ }^{2}$ Pendidikan Islam menurut Syafaruddin adalah suatu proses yang melatih perasaan murid-murid dengan cara sedemikian rupa sehingga dalam sikap hidup, tindakan, keputusan dan pendekatan mereka terhadap segala jenis pengetahuan mereka yang di pengaruhi dengan nilai-nilai spiritual dan sangat sadar akan nilai-nilai Islam. ${ }^{3}$ Menurut Hasan Langgulung pengertian ilmu pendidikan Islam adalah suatu proses penyiapan generasi muda untuk mengisi peran memindahkan pengetahuan, dan nilai-nilai Islam yang dijelaskan dengan fungsi manusia untuk beramal di dunia dan memetik hasinya di akhirat. ${ }^{4}$ Pendidikan Islam juga dapat diartikan suatu sistem kependidikan yang mencakup seluruh aspek kehidupan yang dibutuhkan oleh hamba Allah,

\footnotetext{
${ }^{2}$ Zakiah Daradjat dkk, Ilmu Pendidikan Islam (Jakarta: Bumi Aksara, 2014), cet. ke-11, h.
} 25.

${ }^{3}$ Syafaruddin, Kapita Selekta Pendidikan (Medan: IAIN Press, 1999), h. 12. 94.

${ }^{4}$ Hasan Langgulung, Asas-asas pendidikan Islam (Jakarta: Pustaka Al-Husni, 1999), h. 
sebagaimana Islam telah menjadi pedoman bagi seluruh aspek kehidupan manusia, baik duniawi maupun ukhrawi.

Jadi, dapat kita pahami bahwasanya maksud dari permasalahan pendidikan Islam di Indonesia ialah sejumlah persoalan atau problematika yang terdapat di dalam penyelenggaraan pendidikan Islam yang dihadapi oleh Negara ini dan usaha-usaha untuk mencari solusi terbaik dari setiap permasalahan tersebut.

\section{Pendidikan Islam dalam Perspektif}

Kelembagaan pendidikan sebagai tempat belajar atau menuntut ilmu mempunyai peranan penting dalam upaya proses belajar mengajar antara pendidik dan peserta didik. Karenanya Nabi saw. memberikan petunjuk kepada sekolompok orang yang berkumpul di rumah, di masjid atau di lingkungan masyarakat supaya mengajarkan Alquran. Petunjuk Nabi saw. ini telah menginspirasi para penyelenggara pendidikan untuk menyiapkan atau memanfaatkan tempat di mana saja terdapat orang yang dapat menjangkaunya untuk belajar agama dan ilmu pengetahuan lainnya.

Charles Michael Stanton, menggolongkan lembaga pendidikan Islam ke dalam dua bentuk, yaitu "lembaga pendidikan formal yang mengajarkan pengetahuan agama, dan pendidikan nonformal yang mengajarkan pendidikan umum termasuk filsafat". ${ }^{5}$ George Makdisi, dalam hal yang sama menyebutnya "sebagai lembaga pendidikan eksklusif (tertutup) yang hanya mengajarkan pengetahuan agama, dan lembaga pendidikan inklusif (terbuka) yang mengajarkan pengetahuan umum". 6

Pendidikan adalah solusi yang sangat strategis dalam upayamembangun moralitas bangsa, karenanya pendidikan seyogianya dipahami sebagai suatu proses bukan sebagai suatu seni ataupun teknik, pernyataan ini diperkuat oleh pendapat Mortimer J. Adler, yang mengartikan pendidikan sebagai proses semua kemampuan manusia dan dapat dipengaruhi oleh pembiasaan, disempurnakan dengan kebiasaan-kebiasaan yang baik melalui sarana yang secara artistik dibuat

${ }^{5}$ Charles Michael Stanton, Pendidikan Tinggi dalam Islam, terj. Afandi dan Hasan Asari (Jakarta: Logos, 1994), h. 25.

${ }^{6}$ George Makdisi, Typology of Institutions of Learning, (An Antology Studies), Issa J.Boulatta (Montreal: McGill Indonesia IAIN Development Project, 1992), h. 16. 
dan dipakai oleh siapapun untuk membantu orang lainatau dirinya sendiri dalam rangka mencapai tujuan yang ditetapkanyaitu kebiasaan yang baik. ${ }^{7}$

Berbeda dengan Herman H. Horne, ia mengatakan "Pendidikanharus dipandang sebagai suatu proses penyesuaian diri manusia secara timbal balik dengan alam sekitar, dengan sesama manusia dan dengan tabiat tertinggi dari kosmos. ${ }^{8}$ Pendidikan merupakan perkembangan yang terorganisasi dari semua potensi-potensi manusia, moral, intelektual dan jasmani oleh dan untuk kepribadian individualnya dan kegunaan masyarakatnya yang diharapkan agar semua aktivitasnya sesuai dengan tujuan akhir hidupnya. ${ }^{9}$

Menurut Konfisius dan Socrates pendidikan dipahami sebagaipencarian ilmu pengetahuan dan berbuat kebaikan yang dilakukan seumur hidup. Dalam penerapannya, pendidik harus menanamkan tujuan pendidikan kepada siswa untuk senang belajar dan keinginan untuk meraih hidup yang lebih baik. Untuk mencapai tujuan ini maka kurikulum harus menjadi salah satu landasan untuk pengembangan nilai-nilai kebaikan dan spiritual bagi siswa. ${ }^{10}$ Sedangkan agama Islam yang membawa nilai-nilai dan norma-norma kewahyuan bagi kepentingan hidup manusia di atas bumi, bersifat aktual dan fungsional bila diinternalisasikan ke dalam pribadi melalui proses kependidikan yang konsisten terarah.

Oleh karena itu, proses kependidikan Islam memerlukan konsepkonsep yang dapat dikembangkan menjadi teori-teori yang teruji dalam aplikasinya di lapangan. Bangunan teoritis kependidikan Islamakan dapat berdiri tegak di atas pondasi pandangan dasar (filosofi) yang telah digariskan oleh Allah dalam Alquran. Apa yang terjadi sekarang adalah akibat logis dari perubahan sosial di berbagai sektor kehidupan umat manusia beserta nilai-nilainya yang juga ikut mengalami pergeseran telah memaksa pendidikan Islam harus merubah strategi dan metode operasionalnya. Perubahan strategi danmetode menuntut adanya

\footnotetext{
${ }^{7}$ Mortimer J. Adler, Philosophies of Education (Chicago : University Chicago Press, 1962), h. 209.

${ }^{8}$ Herman H. Horne, An Idealistic Philoshophies Of Education (Chichago : University Chicago Pres, 1962), h. 140.

${ }^{9}$ Ihsan Hamdani, Filsafat Pendidikan Islam (Bandung, Pustaka Setia, 2007), h. 28.

${ }^{10}$ Charlene Tan, Philosophical Reflections For Education, Chapter 1, Philosopgers onEducation (London: Institut of Education University of London), h. 3.
} 
perombakan model sampai denganinstitusinya, sehingga lebih efektif dan efisien dalam arti pedagogis, sosiologis dan kultural. ${ }^{11}$

Pendidikan Islam adalah studi tentang sistem dan proseskependidikan yang berdasarkan Islam untuk mencapai produk atau tujuannya baik secara teoritis maupun praktis. ${ }^{12}$ Dalam pandanganZaini seperti dikutip Ahmad Syafi'i Ma'arif, ia berpendapat bahwa Pendidikan Islam diartikan sebagai usaha pengembangan fitrah manusia dengan ajaran Islam, agar terwujud kehidupan manusia yang makmur dan bahagia. ${ }^{13}$

Dalam perspektif lain, pendidikan Islam adalah merupakanproses pembimbingan, pembelajaran dan atau pelatihan terhadap manusia agar nantinya menjadi orang Islam yang mampu melaksanakan peran sebagai seorang muslim. ${ }^{14}$ Dalam pengertian yang sama pendidikan Islam dipahami sebagai bimbingan jasmani-rohani berdasarkan hukum-hukum Islam menuju kepada terbentuknya kepribadian utama menurut ukuran-ukuran Islam. ${ }^{15}$

Sedangkan pendidikan Islam menurut Omar Muhammad Al-Toumy alSyaebani seperti dikutip oleh Arifin, diartikan sebagai usaha mengubah tingkah laku individu dalam kehidupan pribadinya atau kehidupan masyarakatnya dan kehidupan alam sekitarnya melalui proses kependidikan yang dilandasi dengan nilai-nilai Islam. ${ }^{16}$

Uraian di atas mendeskripsikan bahwa pendidikan Islam berartisuatu proses yang komprehensif tentang pengembangan kepribadian manusia secara keseluruhan, yang meliputi intelektual, spiritual, emosi dan fisik, sehingga seorang muslim disiapkan dengan baik untuk dapat melaksanakan tujuan-tujuan kehadirannya oleh Tuhan sebagai hamba dan wakil-Nya di dunia.

\footnotetext{
${ }^{11}$ M. Arifin, Kapita Selekta Pendidikan Islam dan Umum (Jakarta: Bumi Aksara, 1995), h.2-3.

${ }^{12}$ M. Arifin, Ilmu Pendidikan Islam (Jakarta: Bumi Aksara, 1993), h.11.

${ }^{13}$ Ahmad Syafii Ma'arif, Pendidikan Berparadigma Profentik (Yogyakarta: UGM Press, 2004), h. 50.

${ }^{14}$ Tadjab, Dasar-dasar Kependidikan Islam (Surabaya: Karya Aditama, 1996), h.12.

${ }^{15}$ Imam Bawani, Segi-segi Pendidikan Islam (Surabaya: Al-Ikhlas, 1986), h. 28.

${ }^{16}$ M. Arifin, Filsafat Pendidikan Islam (Jakarta: Bumi Aksara, 1993), h. 14.
} 


\section{Penataan Pendidikan Islam}

Pendidikan Islam di Indonesia merupakan salah satu variasi dari konfigurasi sistem pendidikan nasional. Tetapi pada kenyataannya pendidikan Islam tidak memiliki kesempatan yang luas untuk bersaing dalam membangun umat yang besar ini. Terasa janggal danlucu, dalam komunitas masyarakat muslim terbesar, pendidikan Islam tidak mendapat kesempatan yang luas untuk bersaing dalam membangun umat yang besar ini. Selain itu, paradigma birokrasi tentang pendidikan Islam selama ini lebih didominasi pendekatan sektoral dan bukan pendekatan fungsional, sebab pendidikan Islam tidak dianggap bagian dari sektor pendidikan lantaran urusannya tidak di bawah Depdiknas Maka, perhatian pemerintah yang dicurahkan pada pendidikan Islam sangatlah kecil porsinya, padahal masyarakat Indonesia selalu diharapkan agar tetap berada dalam lingkaran masyarakat yang sosialistis religius. ${ }^{17}$ Dari sinilah timbul pertanyaan, bagaimanakah kemampuan pendidikan Islam di Indonesia untuk menata, mengatasi, dan menyelesaikan problem-problem yang dihadapi menuju pendidikan bermutu dan unggul.

Langkah awal yang diperhatikan untuk melakukan penataanpendidikan Islam, harus menganalisis dari aspek kekuatan, kelemahan, kesempatan, dan ancaman. Pertama, pendidikan Islam (pesantren, madrasah, sekolah yang bercirikan Islam, dan perguruan tinggi) lebih besar $>80 \%$ dikelola oleh swasta. Dalam pengelolaannya lebih percaya dan hormat pada ulama, percaya bahwa guru mengajarkan sesuatu yang benar, panggilan agama, ibadah, ikhlas, murah, merakyat. Hal ini merupakan kekuatan (strengt) dalam pengelolaan pendidikan Islam. Kedua, kelemahan (weakness), bahwa pendidikan Islam posisinya lemah, tidak profesional hampir disemua sektor dan komponennya, stress, terombangambing antara jati dirinya, apakah ikut model sekolah umum atau antara ikut Kemendiknas dan Kemenag. Belum ada sistem yang mantap dalam pengembangan model pendidikan agama dan pendidikan keagamaan. Ketiga, kesempatan (opportunities), bahwa dalam UU No.20 Tahun 2003 memberi kesempatan atau momentum pengembangan pendidikan agama dan keagamaan.

\footnotetext{
${ }^{17}$ Muslih Usa, Pendidikan Islam di Indonesia, Antara Cita dan Fakta: Suatu Pengantar (Yogyakarta:Tiara Wacana, 1991), h. 11.
} 
Pendidikan Islam diakui sama dengan pendidikan yang lain. Keempat, ancaman (treat), bahwa banyak lembaga pendidikan lain yang lebih tangguh dan berkualitas, Ilmu dan teknologi yang berkembang sangat pesat berlum terkejar oleh pendidikan Islam, pendidikan Islam kehilangan jati dirinya, pendidikan Islam selalu menjadi warga kelas dua,tercabut dari akar budaya komunitas muslimnya. Dalam perspektifpendidikan, mungkin akan bertanya mampukah kita menciptakan dan mengembangkan sistem pendidikan Islam yang menghasilkan lulusan-lusan yang "mampu memilih" tanpa kehilangan peluang dan jati dirinya? ${ }^{18}$

Perkembangan pendidikan Islam pada akhir-akhir inisecara berangsurangsur mulai terasa kemajuannya, hal ini terbukti dengan berdirinya lembagalembaga pendidikan Islam dan beberapa model pendidikan yang ditawarkan, yang menunjukkan harapan untuk mampu bersaing. Tetapi masih banyak yang memerlukan penataan. Maka untuk menuju pendidikan yang bermutu dan unggul, pendidikan Islam hendaknya berupaya maksimal untuk membenahi dan melakukan penataan kembali terhadap masalah internalnya, seperti persoalan manajemen, kemampuan kepemimpinan, kompetensi dan profesional guru. Manajemen pendidikan yang bersifat klasik harus ditinggalkan dan berfokus ke manajemen berbasis mutu. Manajemen memiliki visi, missi, goalsdan strategi yang akan diterapkan dalam mencapai tujuan. Namun visi, missi dan goals pun jangan hanya akan menjadi tumpukan berkas perencanaan yang tidak dapat diwujudkan secara nyata apabila kita tidak memiliki rencana strategi yang baik dan tepat.

Dari paparan di atas, menurut hemat penulis bahwa inovasiatau penataan fungsi pendidikan Islam harus dilakukan, terutama pada sistem pendidikan persekolahan harus diupayakan secara terus menerus, berkesinambungan, berkelanjutan, sehingga usahanya dapat menjangkau pada perluasan dan pengembangan sistem pendidikan Islam luar sekolah. Harus dilakukan inovasi kelembagaan dan tenaga kependidikan. Tenaga kependidikan harus ditingkatkan etos kerja dan profesionalismenya. Perbaikan pada aspek materi (kurikulum), pendekatan, dan metodologi yang masih berorientasi pada sistem tradisional, perbaikan pada aspekmanajemen pendidikan itu sendiri. Tetapi usaha melakukan

\footnotetext{
${ }^{18}$ Mastuhu, Menata Ulang Pemikiran Sistem Pendidikan Nasional dalam Abad 21 (Yogyakarta: Safiria Insania Press dan MSI, 2003), h. 10.
} 
inovasi tidak hanya sekedar tanbal sulam, tetapi harus secara mendasar dan menyeluruh, mulai dari fungsi, tujuan, metode, strategi, materi (kurikulum), lembaga pendidikan, dan pengelolaannya. Dengan kata lain, penataan pendidikan Islam haruslah bersifat komprehensif dan menyeluruh, baik pada tingkat konsep maupun penyelenggaraan; tidak lagi adhoc dan incremental seperti sering terjadi di masa silam. ${ }^{19}$ Penataan fungsi pendidikan Islam, tentu dengan memperhatikan dunia kerja, sebab dunia kerja mempunyai andil dan rentang waktu yang cukup besar dalam jangka kehidupan pribadi dan kolektif.

\section{Problematika/Permasalahan Pendidikan Islam di Indonesia}

Sebelum memaparkan permasalahan pendidikan Islam di Indonesia disini penulis akan menyebutkan problematika pendidikan secara umum. Indonesia saat ini berada dalam situasi transisi dari era sentralisasi ke era desentralisasi, upaya pembentukan kebijakan, implementasi kebijakan dan evaluasinya yang dulu dilakukan secara terpusat oleh aparat pemerintah pusat, sekarang didistribusikan secara desentralisasi ke daerah-daerah. Demikian juga halnya urusan pendidikan, terjadi perubahan paradigma yang dulunya sarwa Negara kini mulai berorientasi pada aspirasi masyarakat. Sistem dan proses pendidikan melakukan repositioning. ${ }^{20}$ Situasi dan kondisi yang demikian jelas akan menimbulkan banyak sekali problematika yang cukup kompleks, antara lain: a. Unsur guru/pendidik. Meliputi rendahnya kualitas guru, rendahnya profesionalisme dan kompetensi guru, dan rendahnya gaji guru. b. Unsur tujuan pendidikan. Meliputi terjadinya disorientasi tujuan pendidikan, depolitisasi kebijakan pendidikan, sistem sentralistik dalam kurikulum, dan certificate oriented. c. Unsur lulusan. Meliputi rendahnya kualitas lulusan pendidikan dan kemerosotan akhlak dan moral. d. Unsur pembiayaan pendidikan. meliputi biaya pendidikan dan ketentuan anggaran. e. Unsur metode dan sarana dan prasarana pendidikan. mencakup

\footnotetext{
${ }^{19}$ AzyumardiAzra,Paradigma Baru Pendidikan Nasional,Rekonstruksi dan Demokratisasi (Jakarta: Penerbit Buku Kompas, 2002), h. 17.

${ }^{20}$ Hamzah B. Uno, Profesi Kependidikan (Jakarta: Bumi Aksara, 2011), h. 6.
} 
pendekatan/metode pembelajaran yang monoton dan rendahnya kualitas sarana fisik. $^{21}$

Sementara itu pendidikan Islam diakui keberadaannya dalam sistem pendidikan yang terbagi menjadi tiga hal. Pertama, Pendidikan Islam sebagai lembaga diakuinya keberadaan lembaga pendidikan Islam secara Eksplisit. Kedua, Pendidikan Islam sebagai Mata Pelajaran diakuinya pendidikan agama sebagai salah satu pelajaran yang wajib diberikan pada tingkat dasar sampai perguruan tinggi. Ketiga, Pendidikan Islam sebagai nilai (value) yakni ditemukannya nilainilai islami dalam sistem pendidikan. Walaupun demikian, pendidikan Islam tidak luput dari problematika yang muncul di era global ini. Terdapat dua faktor dalam problematika tersebut, yaitu faktor internal dan faktor eksternal.

Adapun faktor-faktor internal dalam problematika pendidikan Islam, yaitu:

\section{Faktor Manajemen Pendidikan Islam}

Hujair A. H. Sanaky menjelaskan pada umumnya pendidikan Islam belum mampu menyelenggarakan pembelajaran dan pengelolaan pendidikan yangefektif dan berkualitas. Hal ini tercermin dari kalah bersaing dengansekolah-sekolah yang berada di bawah pembinaan Departemen Pendidikan Nasional (Diknas) yang umumnya dikelola secara modern. ${ }^{22} \mathrm{Hal}$ senada juga disebutkan oleh M. Yunus Abu Bakar yang terletak pada a. Ketidakjelasan tujuan yang hendak dicapai, b. Ketidakserasian kurikulum terhadap kebutuhan masyarakat, c. Kurangnya tenaga pendidik yang berkualitas dan profesional, d. Salah pengukuran terhadap hasil pendidikan, e. Belum jelasnya landasan yang dipergunakan untuk menetapkan jenjang tingkat pendidikan mulai dari tingkat dasar hingga ke perguruan tinggi, dan $\mathrm{f}$. Rendahnya kreatifitas lulusan dalam menciptakan lowongan kerja sendiri. ${ }^{23}$

2. Faktor Kompensasi Profesional Guru/Dosen yang Masih Sangat Rendah

Kesejahteraan guru merupakan aspek penting yang harus diperhatikan oleh pemerintah dalam menunjang terciptanya kinerja yang semakin membaik di kalangan pendidik. Berdasarkan UU No.14/2005 tentang Guru dan Dosen, pasal

\footnotetext{
${ }^{21}$ M. Yunus Abu Bakar, "Problematika Pendidikan Islam di Indonesia," dalam Dirasat vol. 1, h. 103-113.

${ }^{22}$ Hujair A. H. Sanaky, "Permasalahan dan Penataan Pendidikan Islam Menuju Pendidikan yang Bermutu," dalam el-Tarbawi, vol. I, h. 87.

${ }^{23}$ Bakar, "Problematika Pendidikan Islam di Indonesia, h. 114.
} 
14 sampai dengan 16 menyebutkan tentang Hak dan Kewajiban diantaranya, bahwa hak guru dalam memperoleh penghasilan adalah di atas kebutuhan hidup minimum dan jaminan kesejahteraan sosial, mendapatkan promosi dan penghargaan, berbagai fasilitas untuk meningkatkan kompetensi, berbagai tunjangan seperti tunjangan profesi, fungsional, tunjangan khusus bagi guru di daerah khusus, serta berbagai maslahat tambahan kesejahteraan.

Fenomena gaji guru Indonesia sangat jauh tertinggal bila dibanding dengan negeri tetangga seperti Malaysia, Brunai, Singapura dan Thailand. Gaji seorang profesor di Indonesia sangat jauh dibanding di negara lain. Apalagi kalau kita perhatikan kesejahteraan guru-guru di tingkat bawah, lebih-lebih para guru swasta. Mereka sangat mengalami kesusahan secara material. Kesenjangan kesejahteraan guru swasta dan negeri menjadi masalah lain yang muncul. Di lingkungan pendidikan swasta, masalah kesejahteraan masih sulit mencapai taraf ideal. Akibatnya tentu saja sangat berpengaruh dengan tingkat profesionalisme mereka. ${ }^{24}$ Fakta lain yang memprihatinkan, seorang yang menggeluti profesi guru lebih dari 39 tahun ternyata gaji pokoknya lebih rendah dari calon pegawai BUMN yang masa kerjanya kurang dari satu tahun. ${ }^{25}$ Dengan pendapatan seperti itu, terang saja, banyak guru terpaksa melakukan pekerjaan sampingan. Ada yang mengajar lagi di sekolah lain, memberi les/prifat pada sore dan malam hari, menjadi tukang ojek, pedagang buku/LKS, pedagang pulsa dan sebagainya.

3. Faktor Kepemimpinan Sekolah/Madrasah yang Lemah

Tidak sedikit kepala-kepala madrasah yang tidak memiliki visi, dan misiuntuk mau ke mana pendidikan akan dibawa dan dikembangkan. Kepala madrasah seharusnya merupakan simbol keunggulan dalam kepemimpinan, moral, intelektual dan profesional dalam lingkungan lembaga pendidikan formal, ternyata sulit ditemukan di lapangan pendidikan Islam. Pimpinan pendidikan Islam bukan hanya seringkurang memiliki kemampuan dalam membangun komunikasi internal dengan para guru, melainkan juga lemah dalam komunikasi dengan masyarakat, orang tua, dan pengguna pendidikan untuk kepentingan penyelenggaraan pendidikan yang berkualitas. Biasanya pendekatan yang digunakan adalah pendekatan birokratis daripada pendekatan kolegial

\footnotetext{
${ }^{24}$ Sukadi, Guru Powerful Guru Masa Depan (Bandung: Qolbu, 2006), h. 29.

${ }^{25}$ H.A. Malik Fajar, Visi Pembaruan Pendidikan Islam (Jakarta: LP3NI, 1998), h. 210.
} 
profesional. Mengelola pendidikan bukan berdasar pertimbangan profesional, melainkan pendekatan like anddislike, dengan tidak memiliki visi dan misi yang jelas. ${ }^{26}$ Abu Bakar menyebutkan bahwa kelemahan pimpinan pendidikan Islam secara umum meliputi tiga aspek, yaitu: a. Lemahnya pemimpin dalam komunikasi dan negosiasi, b. Pimpinan pendidikan Islam kurang memiliki kemampuan dalam membangun komunikasi internal dengan para guru, dan c. Pimpinan pendidikan Islam lemah dalam komunikasi dengan masyarakat, orang tua, dan pengguna pendidikan untuk kepentingan penyelenggaraan pendidikan yang berkualitas. $^{27}$

Rendahnya mutu dari SDM pengelola pendidikan secara praktis tentu dapat menghambat keberlangsungan proses pendidikan yang berkualitas, sehinggaadaptasi dan sinkronisasi terhadap berbagai program peningkatan kualitas pendidikan juga akan berjalan lamban pula.

Sedangkan faktor-faktor eksternal dalam problematika pendidikan Islam, yaitu:

1. Perlakuan Diskriminatif Pemerintah terhadap Pendidikan Islam

Pemerintah selama ini cenderung menganggapdan memperlakukan pendidikan Islam sebagai anak tiri, khususnyasoal dana dan persoalan lain. Katakan saja, alokasi dana yangdiberikan pemerintah sangat jauh perbedaannya dengan pendidikan yang berada di lingkungan Diknas. Maka, terlepas itu semua, apakah itu urusan Kemenag atau Kemendiknas, mestinya alokasi anggaran negara pada pendidikan Islam tidak terjadi kesenjangan, toh pendidikan Islam juga bermisi untuk mencerdaskan bangsa, sebagaimana juga misi yang diemban oleh pendidikan umum.

2. Dikotomi antara Ilmu Agama dan Ilmu Umum.

Masalah besar yang dihadapi dunia pendidikan Islam adalah dichotomy dalam beberapa aspek yaitu antara Ilmu Agama dengan Ilmu Umum, antara Wahyu dengan Akal setara antara Wahyu dengan Alam. Munculnya problem dikotomi dengan segala perdebatannya telah berlangsung sejak lama. Boleh dibilang gejala ini mulai tampak pada masa-masa pertengahan. Menurut Rahman, dalam melukiskan watak ilmu pengetahuan Islam zaman pertengahan menyatakan

\footnotetext{
${ }^{26}$ Sanaky, Permasalahan dan Penataan Pendidikan Islam, h. 87.

${ }^{27}$ Abu Bakar, Problematika Pendidikan Islam, h. 115.
} 
bahwa, muncul persaingan yang tak berhenti antara hukum dan teologi untuk mendapat julukan sebagai mahkota semua ilmu. ${ }^{28}$

\section{Certificate Oriented}

Mencari ilmu hanya merupakan sebuah proses untuk mendapatkan sertifikat atau ijazah saja, sedangkan semangat dankualitas keilmuan menempati prioritas berikutnya.

4. Lack of Spirit of Inquiry

Persoalan besar lainnya yang menjadi penghambat kemajuan dunia pendidikan Islam ialah rendahnya semangat untuk melakukan penelitian/penyelidikan.

\section{To General Knowledge}

Kelemahan dunia pendidikan Islam berikutnya adalah sifat ilmu pengetahuannya yang masih terlalu general/umum dan kurang memperhatikan kepada upaya penyelesaian masalah (problem solving). Produk-produk yang dihasilkan cenderung kurang membumi dan kurang selaras dengan dinamika masyarakat.

\section{Memorisasi}

Belajar lebih banyak bersifat studi tekstual daripada pemahaman pelajaran yang bersangkutan. Hal ini menimbulkan dorongan untuk belajar dengan sistem hafalan (memorizing) daripada pemahaman yang sebenarnya. ${ }^{29}$

7. Paradigma birokrasi tentang pendidikan Islam selama ini lebih didominasi oleh pendekatan sektoral dan bukan pendekatan fungsional. Pendidikan Islam tidak dianggap bagian dari sektor pendidikan lantaran urusannya tidak di bawah Kemendiknas. ${ }^{30}$

8. Adanya Pandangan Sikap Diskriminatif terhadap Produk atau Lulusan Pendidikan Islam

Paradigma masyarakat terhadap lembaga pendidikan Islam masih sebelah mata. Lembaga pendidikan Islam merupakan alternatif terakhir setelah tidak dapat diterima di lembaga pendidikan di lingkungan Kemendiknas. Pandangan

\footnotetext{
${ }^{28}$ Mujahid Damopolii, "Problematika Pendidikan Islam dan Upaya-Upaya Pemecahannya," dalam Tadbir, vol. 3, h. 78.

${ }^{29}$ Ibid., h. 78-79.

${ }^{30}$ Abu Bakar, Problematika Pendidikan Islam, h. 115.
} 
masyarakat yang demikian menjadi indikator rendahnya kepercayaan mereka terhadap lembaga pendidikan Islam. ${ }^{31}$

\section{Langkah-Langkah Mengatasi Permasalahan Pendidikan Islam di Indonesia}

Dari pemetaan problematika pendidikan Islam di atas, penulis mencoba berikhtiar untuk memahami dan memberikan solusi alternatif, meliputi sebagai berikut:

1. Masalah pembelajaran dikotomi, solusi yang dapat ditawarkan adalah mengintegrasikan antar submata pelajaran agama, dan antara mata pelajaran agama dengan mata pelajaran umum selain agama. Sehingga menghasilkan pembelajaran yang diwarnai oleh nilai-nilai keagamaan.

2. Masalah minimnya kesejahteraan guru, hendaknya disadari oleh pemerintah, orang tua murid, dan masyarakat. Karena guru adalah ujung tombak kesejahteraan suatu bangsa.

3. Masalah kualitas, relevansi/efisiensi eksternal, elitisme, dan manajemen dapat diatasasi bila pemerintah, dunia pendidikan, dan dunia usaha duduk semeja untuk merumuskan link and match yang sinergis.

4. Melakukan orientasi pendidikan Islam yang sesuai dengan perkembangan zaman dan kebutuhan masyarakat. Orientasi tersebut ialah sebagai berikut: ${ }^{32}$

a. Pendidikan Islam harus diorientasikan untuk menciptakan "kesadaran kritis" masyarakat. Sehingga dengan kesadaran kritis ini akan mampu menganalisis hubungan faktor-faktor sosial dan kemudian mencarikan jalan keluarnya.

b. Adanya proses humanisasi dalam pendidikan Islam dimaksudkan sebagai upaya mengembangkan manusia sebagai makhluk hidup yang tumbuh dan berkembang dengan segala potensi yang ada padanya. Manusia dapat dibesarkan potensi jasmaninya dan diberdayakan potensi rohaninya agar dapat berdiri sendiri dan dapat memenuhi kebutuhan hidupnya.

c. Pendidikan Islam sebagai pembinaan akhlaq al-karimah, akhlak merupakan domain penting dalam kehidupan masyarakat, apabila di era

\footnotetext{
${ }^{31}$ Ibid., h. 116.

${ }^{32}$ Ahmad Tantowi, Pendidikan Islam di Era Transformasi Global (Semarang: Pustaka Rizki Putra, 2009), cet. ke-1, h. 90.
} 
globalisasi ini. Tidak adanya akhlak dalam tata kehidupan masyarakat akan menyebabkan hancurnya masyarakat itu sendiri.

5. Merubah pola pendidikan Islam indoktrinasi menjadi pola partisipatif antara guru dan murid. Pola ini memberikan ruang bagi siswa untuk berpikir kritis, optimis, dinamis, inovatif, memberikan alasan-alasan yang logis, bahkan siswa dapat pula mengkritisi pendapat guru jika terdapat kesalahan. Intinya, pendekatan epistemologi ini menuntut pada guru dan siswa untuk sama-sama aktif dalam proses belajar mengajar.

6. Orientasi pendidikan Islam ditekankan pada pertumbuhan yang integrasi antara iman, ilmu, amal, dan akhlak. Semua dimensi ini bergerak saling melengkapi satu sama lainnya, sehingga perpaduan seluruh dimensi ini mampu menelorkan manusia paripurna yang memiliki keimanan yang kokok, kedalaman spritual, keluasan ilmu pengetahuan, dan memiliki budi pekerti mulia yang berpijak pada "semua bersumber dari Allah, semua milik Allah, dan akan kembali kepada Allah".

7. Merubah pendekatan dari pendekatan teoritis atau konseptual pada pendekatan kontekstual atau aplikatif. Dari sini pendidikan Islam harus menyediakan berbagai media penunjang untuk mencapai hasil pendidikan yang diharapkan.

\section{Penutup}

Melalui uraian dan penjelasan makalah di atas, maka penulis dapat menyimpulkan sebagai berikut:

Pertama, pendidikan di Indonesia mengalami berbagai problema yang sangat mendasar dan multidimensional, yaitu antara lain rendahnya kualitas pendidikan secara umum, anggaran yang tidak sesuai atau rendah, sarana dan prasarana yang kurang memadai. Selain itu masalah keguruan juga mengalami berbagai problematika yang tidak kalah peliknya antara lain rendahnya tugas guru, kurang profesional dalam melaksanakan tugas keguruan, juga kurang efektifnya proses pembelajaran yang terjadi.

Kedua, permasalahan/problematika pendidikan Islam di Indonesia ini dapat dibagi menjadi dua, yaitu faktor internal yang di dalamnya ada: faktor manajemen pendidikan, faktor kompensasi profesional guru/dosen yang masih 
rendah, dan faktor kepemimpinan sekolah/madrasah yang masih lemah. Dan faktor eksternal yang meliputi faktor diskriminasi pemerintah terhadap pendidikan Islam, dichotomic, to general knowledge, lack of spririt of inquiry, memorisasi, dan certificate oriented, paradigma birokrasi pendidikan Islam lebih didominasi oleh pendekatan sektoral dan bukan pendekatan fungsional, dan adanya pandangan sikap diskriminatif terhadap produk atau lulusan pendidikan Islam.

Ketiga, solusi dari permasalahan/problematika tersebut antara lain melakukan perubahan atas kesalahan pendidikan, depolitisasi kebijakan pendidikan, mengintegrasikan antar sub matapelajaran agama, dan antara mata pelajaran agama dengan mata pelajaran umum selain agama, Melakukan orientasi pendidikan Islam yang sesuai dengan perkembangan zaman dan kebutuhan masyarakat, dan pendidikan Islam diorientasikan sebagai proses penyadaran, sebagai proses humanisasi, dan sebagai pembinaan akhlaq al-karimah. 


\section{Pustaka Acuan}

Abu Bakar, M. Yunus. "Problematika Pendidikan Islam di Indonesia," dalam Dirasat vol. 1.

Adler,Mortimer J. Philosophies of Education. Chicago : University Chicago Press, 1962.

Arifin,M. Filsafat Pendidikan Islam. Jakarta: Bumi Aksara, 1993.

Arifin, M. Ilmu Pendidikan Islam. Jakarta: Bumi Aksara, 1993.

Arifin, M. Kapita Selekta Pendidikan Islam dan Umum. Jakarta: Bumi Aksara, 1995.

Azra,Azyumardi Paradigma Baru Pendidikan Nasional, Rekonstruksi dan Demokratisasi. Jakarta: Penerbit Buku Kompas, 2002.

Bawani,Imam.Segi-segi Pendidikan Islam. Surabaya: Al-Ikhlas, 1986.

Buchori, Mochtar. Spektrum Problematika Pendidikan di Indonesia. Yogyakarta: Tiara Wacana 1994.

Damopolii, Mujahid. "Problematika Pendidikan Islam dan Upaya-Upaya Pemecahannya," dalam Tadbir, vol. 3.

Daradjat, Zakiah dkk.Ilmu Pendidikan Islam. Jakarta: Bumi Aksara, 2014. cet. ke11.

Fajar,H.A. Malik. Visi Pembaruan Pendidikan Islam. Jakarta: LP3NI, 1998.

Hamdani,Ihsan.Filsafat Pendidikan Islam. Bandung, Pustaka Setia, 2007.

Horne,Herman H. An Idealistic Philoshophies Of Education. Chichago : University Chicago Pres, 1962.

Langgulung,Hasan.Asas-asas pendidikan Islam. Jakarta: Pustaka Al-Husni, 1999.

Ma'arif,Ahmad Syafii.Pendidikan Berparadigma Profentik. Yogyakarta: UGM Press, 2004.

Makdisi,George.Typology of Institutions of Learning, (An Antology Studies), Issa

J. Boulatta. Montreal: McGill Indonesia IAIN Development Project, 1992. 
Mastuhu.Menata Ulang Pemikiran Sistem Pendidikan Nasional dalam Abad 21. Yogyakarta: Safiria Insania Press dan MSI, 2003.

Sanaky,Hujair A. H. "Permasalahan dan Penataan Pendidikan Islam Menuju Pendidikan yang Bermutu," dalam el-Tarbawi, vol. I.

Stanton, Charles Michael.Pendidikan Tinggi dalam Islam, terj. Afandi dan Hasan Asari. Jakarta: Logos, 1994.

Sukadi. Guru Powerful Guru Masa Depan. Bandung: Qolbu, 2006.

Syafaruddin.Kapita Selekta Pendidikan. Medan: IAIN Press, 1999.

Tadjab. Dasar-dasar Kependidikan Islam. Surabaya: Karya Aditama, 1996.

Tan,Charlene.Philosophical Reflections For Education, Chapter 1, Philosopgers on Education. London: Institut of Education University of London.

Tantowi,Ahmad.Pendidikan Islam di Era Transformasi Global. Semarang: Pustaka Rizki Putra, 2009. cet. ke-1.

Uno,Hamzah B. Profesi Kependidikan. Jakarta: Bumi Aksara, 2011.

Usa,Muslih Pendidikan Islam di Indonesia, Antara Cita dan Fakta: Suatu Pengantar. Yogyakarta:Tiara Wacana, 1991. 